\title{
High D-dimer levels are associated with prostate cancer
}

\author{
(D) Senad Kalkan ${ }^{1}$ \\ Delahattin Caliskan²
}

1. Bezmialem Vakif University, Faculty of Medicine, Department of Urology, Istanbul, Turkey. 2. Reyap Hospital, Department of Urology, Istanbul, Turkey.

http://dx.doi.org/10.1590/1806-9282.66.5.649

KEYWORDS: Prostatic neoplasms. Thrombophilia. Biomarkers, tumor/blood. Fibrin fibrinogen degradation products.

\section{INTRODUCTION}

Prostate cancer is one of the most common types of cancer among men in the world ${ }^{1}$ and a significant health problem in developed and developing countries $^{2}$. The association between cancer and hemostasis has been shown in several studies ${ }^{3}$. The main risk factors for coagulation activation and thrombosis are aging and malignancy ${ }^{4}$. The increased risk of thrombosis in cancer patients may be associated with high levels of coagulation markers (fibrinogen), and thrombogenesis markers (D-dimer) are likely evidence of this process ${ }^{5}$.

Fibrinogen is an acute-phase protein that is mainly synthesized by hepatocytes and converted into insoluble fibrin by activated thrombin. It is also an important indicator of the coagulation system ${ }^{6}$. The plasma fibrinogen level increases in some circumstances, such as malignancy and systemic inflammation. D-dimer is a degradation product of fibrin which is produced by plasmin-induced fibrinolytic activity ${ }^{7}$. It is a biomarker that indicates the activation of hemostasis and fibrinolysis. Elevated plasma levels may be associated with some scenarios such as cancer, pregnancy, infectious diseases, trauma, surgery, and venous thromboembolism.

When fibrinogen levels are increased, they are deemed to be an unfavorable prognostic factor in some malignancies, such as those of the digestive system, gynecologic malignancies, urologic neoplasms, and soft tissue sarcomas ${ }^{6}$. A high level of D-dimer is a prognostic factor associated with increased mortality risk in patients with brain tumors, lymphomas, breast, lung, stomach, colorectal, pancreatic, and prostate cancers ${ }^{7}$. We investigated the levels of D-dimer and fibrinogen in patients with prostate cancer and benign prostate hyperplasia.

\section{METHODS}

Patients who had a pathological diagnosis of prostate disease by transrectal ultrasound-guided biopsy and transurethral surgery between January 2015 and January 2019 were enlisted. Plasma prostate specific antigen (PSA), free PSA (fPSA), percentage fPSA, D-dimer, and fibrinogen levels were measured before the 
procedures (prostate biopsy and transurethral resection). The percentage of PPSA was calculated as PPSA/ PSA $^{\times} 100$. Venous blood samples were collected into citrate tubes by sterile atraumatic venipunctures. Enzyme-linked immunosorbent assay (ELISA) (Diagnostic Stago, France) and the Clauss method (Sysmex, Japan) techniques were used to measure the plasma D-dimer and fibrinogen levels. Plasma fibrinogen and D-dimer levels were considered to be normal when between $175 \mathrm{mg} / \mathrm{dL}$ and $350 \mathrm{mg} / \mathrm{dL}$ and between Oug/ $\mathrm{mL}$ and $0.5 \mathrm{ug} / \mathrm{mL}$, respectively.Patients with a history of coagulopathy, hematuria, venous or pulmonary embolism, acute or chronic prostatitis, radiotherapy, malignancy, and using anticoagulant therapy were excluded from the study. The patients' data, including PSA, fPSA, percentage of fPSA, D-dimer, and fibrinogen levels, and patient age and pathology reports, were recorded. Patients who had a diagnosis of high-grade prostate intraepithelial neoplasia and atypical small acinar proliferation (9 patients) were excluded from the study. The remaining patients were then divided into two groups; the ones whose pathological report was benign prostate hyperplasia were placed in Group 1 , and those who had prostate cancer in Group 2. The statistical analyses were performed using MedCalc Statistical Software demo version 16.2.0 (MedCalc Software bvba, Ostend, Belgium; https://www.medcalc.org; 2016). The data were verified for normal distribution using the Kolmogorov-Smirnov test and expressed as mean \pm standard deviation (normal distribution), median values, and $\mathrm{p}<0.05$ was considered with statistical significance.

\section{RESULTS}

The current study included 218 patients. There were 161 patients in Group 1 and 57 patients in Group 2. The mean age of the patients was $66.37 \pm 7.96$ years and $69.33 \pm 7.2$ years in Group 1 and Group 2, respectively. The patients' characteristics are listed in Table 1.

There was a statistically significant difference for age, PSA, fPSA, and D-dimer between the groups. In Group 2, D-dimer levels were higher $(0.41 \mathrm{ug} / \mathrm{mL}$ and $0.38 \mathrm{ug} / \mathrm{mL}, p<0.05)$ than in Group 1. The patients were diagnosed using transrectal ultrasound-guided prostate biopsy and transurethral prostate surgery (Figure 1). Transrectal prostate biopsy and transurethral surgery were performed in 72 and 146 patients, respectively.
TABLE 1. PATIENTS' BIOCHEMICAL RESULTS

\begin{tabular}{l|l|l|l} 
& \multicolumn{1}{l}{ Group 1 } & \multicolumn{1}{l}{ Group 2 } & P \\
\hline Patients n(\%) & $161(74)$ & $57(26)$ & \\
\hline Age (years) & $66.37+7.96$ & $69.33+7.2$ & ${ }^{*}<0.05$ \\
\hline PSA $(\mathrm{ng} / \mathrm{ml})$ & 5.93 & 12.74 & ${ }^{*}<0.05$ \\
\hline fPSA $(\mathrm{ng} / \mathrm{ml})$ & 1.2 & 1.94 & ${ }^{*}<0.05$ \\
\hline Fibrinogen $(\mathrm{mg} / \mathrm{dl})$ & 299 & 304 & 0.49 \\
\hline D-dimer $(\mathrm{ug} / \mathrm{ml})$ & 0.38 & 0.41 & ${ }^{*}<0.05$ \\
\hline Diagnosis & & & ${ }^{*}<0.05$ \\
\hline Transurethral resection $\mathrm{n}(\%)$ & $62(38.5)$ & $10(17.5)$ & \\
\hline Prostate Biopsy n(\%) & $99(61.5)$ & $47(82.5)$ & \\
\hline
\end{tabular}

PSA: prostate specific antigen; fPSA: free PSA; "statistically significant

FIGURE 1. THE FINAL IMAGE OF THE PROSTATE AFTER SURGERY

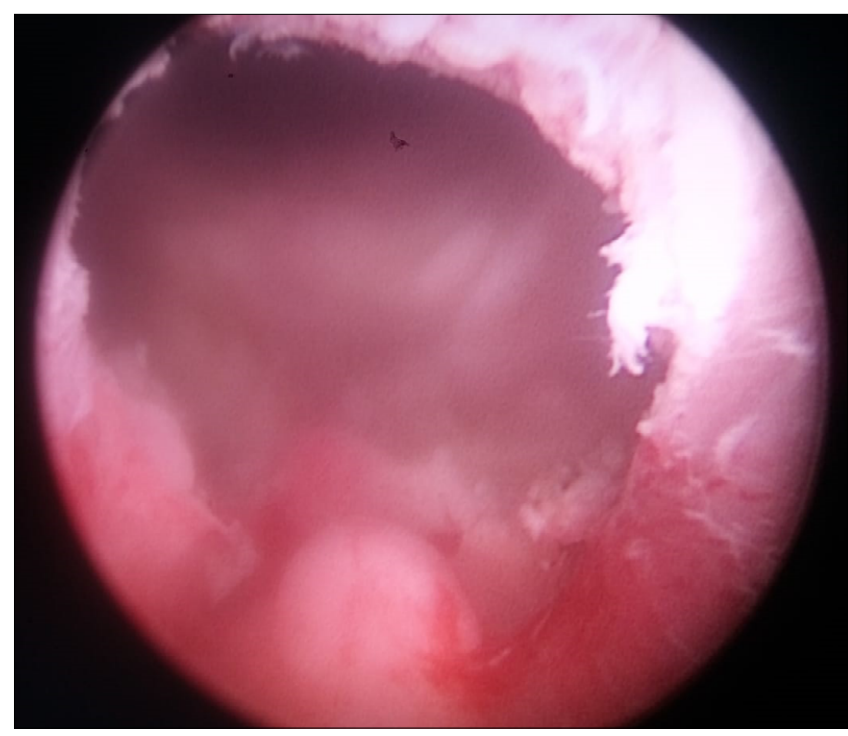

In Group 2, 18 patients were reported as Gleason 6, 14 as Gleason 7, and 13 as Gleason 8. Gleason 9 and Gleason 10 were detected in nine and three patients, respectively (Figure-2).

FIGURE 2. THE GLEASON SCORE OF THE PATIENTS

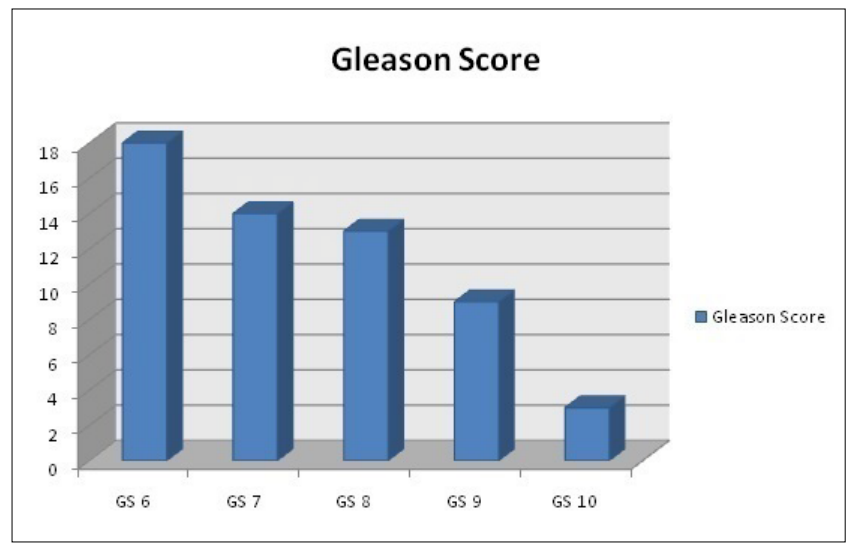




\section{DISCUSSION}

Prostate cancer is the most common type of cancer in men ${ }^{8}$. The digital rectal examination and PSA testing are important screening methods to detect prostate cancer. These screening methods may lead to prostate biopsy, which is necessary to confirm the diagnosis of prostate cancer. A transrectal ultrasound-guided prostate biopsy is the gold standard method for the histopathological diagnosis of prostate cancer ${ }^{9}$. Mochtar et al. ${ }^{10}$ described the transrectal ultrasound-guided sextant prostate biopsy, which is an inaccurate means of cancer detection with 10-30\% of false-negative rates. The European Association of Urology guidelines suggests prostate biopsy by either the transrectal or transperineal approach for the initial diagnosis ${ }^{11}$. The authors reported that the prostate cancer detection rate was $13.3-35 \%$ in patients who underwent six and 12 prostate biopsies, respectively ${ }^{8}$.

The pathogenesis of cancer-associated thrombosis depends on patient characteristics, tumor histology, stage, and treatment-related factors ${ }^{12}$. Abnormalities of the coagulation system have been investigated in cancer patients, and it has been reported that plasma levels of factors were altered ${ }^{13,14}$. In cancer patients, the systematic activation of coagulation occurs, which leads to augmented thrombin generation followed by fibrin formation ${ }^{15}$. It has been suggested that fibrin may contribute to tumor growth and facilitate tumor invasion and metastasis by promoting angiogenesis and the formation of a protective fibrin shield on tumor cells that makes them resistant to endogenous defense mechanisms. The interaction of fibrin, platelets, and tumor cells leads to the formation of aggregates that promote endothelial adhesion and metastatic potential ${ }^{7}$. Fibrin degradation products have strong angiogenic efficacy.

Fibrinogen is an important coagulation system factor and systemic inflammatory marker that enhances the progression and invasive potential of tumor cells through several mechanisms ${ }^{6}$. Firstly, fibrinogen is deposited around solid tumors and provides a stable framework to the extracellular matrix of the tumor. It also serves as a scaffold to support some growth factors to tumor cells, such as vascular endothelial growth factor and fibroblast growth factor, and promotes tumor proliferation and angiogenesis. Tumor cells have fibrinogen receptors, intercellular adhesion molecule-1, and $\alpha 5 \beta 1$ integrin. These receptors play a role as a bridging factor between fibrinogen and tumor cells, thus enhancing the endothelial adhesion of tumor cell emboli in the vasculature of target organs, leading to metastasis. Additionally, fibrinogen promotes $\beta 3$-integrin-mediated adhesion of tumor cells to platelets, and the platelet-tumor cell aggregates thus formed can shield tumor cells from the immune system and lead to an increase of metastatic tumor cells ${ }^{6}$. The fibrinogen levels are increased because of tumor-associated cytokines or endogenous synthesis by tumor cells themselves in cancer patients ${ }^{16}$. The endogenous fibrinogen has a key role in promoting the growth of lung and prostate cancer cells through interaction with fibroblast growth factor ${ }^{17}$. D-dimer is one of the fibrin degradation products, and the level of D-dimer is a result of fibrinolysis activation ${ }^{12}$. Elevated plasma D-dimer levels are seen in patients with various types of cancer because procoagulant factors lead to constitutive activation of the coagulation cascade, which results in thrombin generation followed by fibrin formation ${ }^{18}$. Fibrin may also conversely form a protective shield on malignant tumor cells, protecting them from endogenous defense mechanisms and promoting angiogenesis, invasion, and metastasis of the tumor. Tumor cells themselves may convert fibrinogen to fibrin, and the fibrin is used for support, for the emergence of new vessels, invasion, and remodeling tumor stroma ${ }^{19}$.

Elevated D-dimer levels have been reported in patients with breast, prostate, gynecologic, and lung cancers without clinical thrombosis ${ }^{12}$. D-dimer levels were the highest in patients with pancreatic cancer and lowest in patients with prostate cancer. The authors from the Vienna Cancer and Thrombosis Study reported that an increased D-dimer level was a prognostic parameter associated with increased mortality risk in patients with lymphomas, brain tumors, pancreatic, prostate, breast, lung, stomach, and colorectal cancers ${ }^{7}$. In addition, Ryu et al. ${ }^{20}$ reported that D-dimer levels may support the diagnosis of cryptogenic stroke in critically ill cancer patients. Authors from Korea found that D-dimer levels were significantly higher in patients with prostate cancer than in patients without prostate cancer at prostate biopsy $^{19}$. In another study, the investigators showed a significant increase of D-dimer level in patients with advanced prostate cancer compared with age-matched controls and patients with localized prostate cancer ${ }^{4}$. By contrast, Caine et al. ${ }^{5}$ investigated the D-dimer levels after radical prostatectomy and found no significant difference 3 and 12 months after surgery. There are limited articles about prostate cancer and 
fibrinogen and D-dimer levels in the literature. We found that the D-dimer level was higher in patients with prostate cancer than in other patients with benign prostate hyperplasia $(p<0.05)$ in $2017^{21}$. In the current study, the results were the same, and an elevated D-dimer level was detected in patients with prostate cancer $(p<0.05)$.

The authors found strong evidence that an elevated plasma fibrinogen level was an independent predictor of worse overall survival in patients with solid tumors ${ }^{22}$. Patients with an increased level of fibrinogen have significantly poorer disease-free survival and cancer-specific survival. Thurner et al. ${ }^{16}$ found that there was a significant association between an elevated plasma fibrinogen level and poor cancer-specific and overall survival in patients with prostate cancer. Caine et al. ${ }^{5}$ found a significant fall in fibrinogen level after radical prostatectomy 3 and 12 months after surgery. In a meta-analysis, the authors reported that high pretreatment plasma fibrinogen levels can predict poorer overall and cancer-specific survival in patients with prostate cancer ${ }^{23}$. By contrast, Hong et al. ${ }^{19}$ found that there was no difference between fibrinogen levels in patients with prostate cancer compared with others. That study showed higher fibrinogen levels in patients with advanced prostate cancer than in patients with organ-confined disease, without a significant difference. We found no difference in fibrinogen levels between the groups.

There are some limitations to this study. It includes only one data center, the coagulation parameters (fibrinogen, D-dimer) were not checked again after first measuring the levels, and other hemostatic system factors were not analyzed. The stage of patients with prostate cancer was not homogenous. Finally, conditions such as trauma and inflammatory process, which may affect coagulation parameters, could not be eliminated. Despite these limitations, to the best of our knowledge, this is the largest series from Turkey to investigate the relationship between coagulation parameters and prostate cancer.

In conclusion, patients with prostate cancer presented higher plasma D-dimer levels than the others. Plasma D-dimer level may be a diagnostic marker for prostate cancer if further studies support our findings. Well designed, multicentre, prospective studies are needed to define the relationship between prostate cancer and the coagulation system.

\section{Author's contribuition}

The authors contributed equality for writing, datacollection and supervision.

\section{RESUMO}

OBJETIVO: O câncer de próstata é uma das neoplasias mais comuns em homens. Os principais fatores de risco para a ativação da coagulação e trombose são malignidade e idade mais avançada. O risco de trombose pode estar associado ao aumento do nível dos marcadores de coagulação, tais como o fibrinogênio e D-dímero. O objetivo deste estudo é avaliar a relação entre os marcadores de coagulação e o câncer de próstata.

METODOLOGIA: Este estudo prospectivo incluiu os pacientes que foram submetidos à biópsia de próstata transretal guiada por ultrassonografia e que passaram por cirurgia da próstata entre janeiro de 2015 e janeiro de 2016. Os níveis no plasma de antígeno prostático específico (PSA), PSA livre (fPSA), porcentagem de fPSA, D-dímero e fibrinogênio foram medidos antes dos procedimentos. Os pacientes foram divididos em dois grupos de acordo com os resultados de patologia. Os pacientes com hiperplasia benigna da próstata foram colocados no grupo 1 e os pacientes com câncer de próstata no grupo 2.

RESULTADOS: No total, 76 pacientes foram incluídos neste estudo. Houve um total de 53 pacientes no grupo 1 e 23 pacientes no grupo 2. A idade média dos pacientes e os níveis de PSA, fPSA, fibrinogênio e D-dímero foram, respectivamente, $65.33 \pm 7.47$ anos, $8.21 \pm$ 4.59, $1.41 \pm 0.74 \mathrm{ng} / \mathrm{ml}, 309.75 \pm 80.46 \mathrm{mg} / \mathrm{dl}$ e $0.42 \pm 0.39 \mu \mathrm{g} / \mathrm{ml}$ no grupo 1. No grupo 2, a idade média dos pacientes e os níveis de PSA, fPSA, fibrinogênio e D-dímero foram, respectivamente, $66.08 \pm 6.7$ anos, $145.69 \pm 509.35,7.32 \pm 15 \mathrm{ng} / \mathrm{ml}, 312.16 \pm 69.48 \mathrm{mg} / \mathrm{dl}$, $1.09 \pm 2.11 \mathrm{\mu g} / \mathrm{ml}$. Biópsia da próstata e cirurgia transuretal foram realizadas em $64(\% 84,21)$ e $12(\% 15,79)$ pacientes, respectivamente.

CONCLUSÃO: O presente estudo demonstrou que os níveis de D-dímero no plasma foram maiores em pacientes com câncer de próstata. Novos estudos com um maior número de pacientes são necessários para definir a relação entre câncer de próstata e distúrbios de coagulação.

PALAVRAS-CHAVE: Neoplasias da próstata. Trombofilia. Biomarcadores tumorais/sangue. Produtos de degradação da fibrina e do fibrinogênio. 


\section{REFERENCES}

1. Sungur M, Caliskan S. Awareness of prostate cancer diagnosis and management among Turkish males: a cross sectional study from Çorum. Aging Male. 2019:1-4.

2. Alghamidi IG, Hussain II, Alghamdi MS, El-Sheemy MA. The incidence rate of prostate cancer in Saudi Arabia: an observational descriptive epidemiological analysis of data from the Saudi Cancer Registry 2001-2008. Hematol Oncol Stem Cell Ther. 2014;7(1):18-26.

3. Lyman GH, Khorana AA. Cancer, clots and consensus: new understanding of an old problem. J Clin Oncol. 2009;27(29):4821-6.

4. Kohli M, Fink LM, Spencer HJ, Zent CS. Advanced prostate cancer activates coagulation: a controlled study of activation markers of coagulation in ambulatory patients with localized and advanced prostate cancer. Blood Coagul Fibrinolysis. 2002;13(1):1-5.

5. Caine Gl, Ryan P, Lip GY, Blann AD. Significant decrease in angiopoietin-1 and angiopoietin-2 after radical prostatectomy in prostate cancer patients. Cancer Lett. 2007;251(2):296-301.

6. Wen J, Yang Y, Ye F, Huang X, Li S, Wang Q. The preoperative plasma fibrinogen level is an independent prognostic factor for overall survival of breast cancer patients who underwent surgical treatment. Breast. 2015;24(6):745-50

7. Ay C, Dunkler D, Pirker R, Thaler J, Quehenberger P, Wagner O. High D-dimer levels are associated with poor prognosis in cancer patients. Haematologica. 2012;97(8):1158-64.

8. Ghafoori M, Velayati M, Aliyari Ghasabeh M, Shakiba M, Alavi M. Prostate biopsy using transrectal ultrasonography; the optimal number of cores regarding cancer detection rate and complications. Iran | Radiol. 2015;12(2):e13257.

9. Kocan $\mathrm{H}$. Factors affecting the diagnosis of prostate cancer through 12 quadrant guided prostate biopsy. Aging Male. 2019:1-6.

10. Mochtar CA, Atmoko W, Umbas R, Hamid ARAH. Prostate cancer detection rate in Indonesian men. Asian J Surg. 2018;41(2):163-9.

11. Mottet $N$, van den Bergh RCN, Briers E, Cornford P, De Santis M, Fanti S, et al. EAU Guidelines on Prostate Cancer. 2018. [cited 2019 Aug 12]. Available from: https://uroweb.org/guideline/prostate-cancer/
12. Hanna DL, White RH, Wun T. Biomolecular markers of cancer-associated thromboembolism. Crit Rev Oncol Hematol. 2013;88(1):19-29.

13. Bick RL. Coagulation abnormalities in malignancy: a review. Semin Thromb Hemost. 1992;18(4):353-72.

14. Constantini V, Zacharski LR. Fibrin and cancer. Thromb Haemost. 1993;69(5):406-14.

15. Ay C, Vormittag R, Dunkler D, Simanek R, Chiriac AL, Drach |, et al. D-dimer and prothrombin fragment $1+2$ predict venous thromboembolism in patients with cancer: results from the Vienna Cancer and Thrombosis Study. J Clin Oncol. 2009;27(25):4124-9.

16. Thurner EM, Krenn-Pilko SK, Langsenlehner U, Stajokovic T, Pichler M, Gerger A, et al. The association of an elevated plasma fibrinogen level with cancer-specific and overall survival in prostate cancer patients. World J Urol. 2015;33(10):1467-73.

17. Sahni A, Simpson-Haidaris PI, Sahni SK, Vaday GG, Francis CW. Fibrinogen synthesized by cancer cells augments the proliferative effect of fibroblast growth factor-2 (FGF-2). J Thromb Haemost. 2008;6(1):176-83.

18. Khoury JD, Adcock DM, Chan F, Symanowski JT, Tiefenbacher S, Goodman $\mathrm{O}$, et al. Increases in quantitative $\mathrm{D}$-dimer levels correlate with progressive disease better than circulating tumor cell counts in patients with refractory prostate cancer. Am J Clin Pathol. 2010;134(6):964-9.

19. Hong SK, Ko DW, Park J, Kim IS, Doo SH, Yoon CY, et al. Alteration of antithrombin III and D-dimer levels in clinically localized prostate cancer. Korean J Urol. 2010;51(1):25-9.

20. Ryu IA, Bang Oy, Lee GH. D-dimer levels and cerebral infarction in critically ill cancer patients. BMC Cancer. 2017;17(1):591.

21. Çalışkan S, Sungur M. Fibrinogen and D-dimer levels in prostate cancer: preliminary results. Prostate Int. 2017;5(3):110-2.

22. Perisandis C, Psyrri A, Cohen EE, Engelman J, Heinze G, Perisandis B, et al. Prognostic role of pretreatment plasma fibrinogen in patients with solid tumors: a systematic review and meta-analysis. Cancer Treat Rev. 2015;41(10):960-70

23. Song H, Kuang G, Zhang Z, Ma B, lin I, Zhang Q. The Prognostic value of pretreatment plasma fibrinogen in urological cancers: a systematic review and meta-analysis. J Cancer. 2019;10(2):479-87. 